\title{
UAKTYWNIENIE UCZESTNICTWA WIERNYCH WE MSZY ŚW.
}

Bezsprzecznie stwierdzamy dziś fakt, że lud wszędzie domaga się większej aktywności, tak w życiu politycznym i społecznym, jak również w życiu kościelnym. W tej ostatniej dziedzinie t. zw. ruch liturgiczny, zaaprobowany $w$ jego zdrowych dążeniach przez papieża Piusa XII encykliką Mediator Dei z dnia 20 listopada 1947 r. idzie mu na rękę, głosząc jako naczelna zasadę aktywny udział wiernych w liturgii, a zwłaszcza w jej najwznioślejszej akcji, we mszy św. Hasło to znajduje swe uzasadnienie w dogmatycznej prawdzie o Ciele Mistycznym Jezusa i o powszechnym kapłaństwie chrześcijan, jak również w zwyczaju starożytnego Kościoła, kiedy tak żywo pielęgnowano życie liturgiczne właśnie przy bardzo czynnym udziale wiernych. Ruch liturgiczny zmierza do przywrócenia wiernym dawniejszej aktywnej postawy liturgicznej. Dlatego też duszpasterz dbający o dobro swych owieczek nie może nie popierać tego zdrowego i słusznego postulatu.

Niniejszy artykuł ma na celu dać kapłanom praktyczne wskazówki, jak można wiernych stopniowo wprowadzić w czynny udział w Najsśw. Ofierze. Mamy tu na myśli głównie dorosłych, a nie tyllı́o dzieci.

Nasamprzód trzeba pamiętać, że uaktywnienie iść powinno w kierunku racjonalnym, t. zn. w takin kierunku, jaki przepisuje i wykreśla sama liturgia mszalna. Istotnie sama msza św. przydziela wiernym pewną określoną rolę. I tej reguły należy się trzymać, jeśli praca nie ma zejść na manowce. Należy tedy pytać się zawsze, czego sama msza św. domaga się od wiernych, by ich udział w niej odpowiadał jej istocie i jej treści.

\section{A. MOŹLIWOŚCI}

\section{I.}

I tak na pierwszym miejscu wierni muszą koniecznie na nowo uświadomić sobie, że Msza św. jest istotnie ofiara, a nie tylko sprowadzeniem obecności Pana Jezusa na ołtarz, albo pewnego rodzaju wystawieniem Najśw. Sakramentu, albo przemienieniem komunikantów dla Komunii św. Bezkrwawa ofiara mszalna jest spośród 
wielu aktów czci Boga najlepszym sposobem oddania Trójcy św. należnego jej hołdu, gdyż ofiaruje się w niej sam Jezus Chrystus. Razem z Chrystusem również i Kościót ofiaruje i jest ofiarowany. O tyle więc wierni mogą brać aktywny udział, o ile z całą świadomością i z pełnym zrozumieniem łączą się z Kościołem w tej akcji ofiarnej. Moga więc oni współofiarować Jezusa, a również i siebie samych złożyć Bogu w ofierze przez Jezusa, z Jezusem i w Jezusie.

Temu wewnętrznemu poczuciu ofiarnemu mogad dać wierni wyraz zewnętrzny, który wprawdzie nie jest konieczny, lecz pochwały godny, w ten sposób, że na ofiarowanie złożą jakạś ofiarę materialną, w naszym wypadku jakiś datek pieniężny. Przez to bowiem uzewnętrzniaja swoją wolę złożenia Jezusa w ofierze, gdyż przyczyniają się do zakupienia chleba i wina, w których to postaciach Jezus ofiaruje się na ołtarzu, oraz wolę ofiarowania siebie samych, gdyż zdobywają się na pewną ofiarę ze swoich dóbr.

Za złożoną ofiarę pragnie nas Bóg wynagrodzić swoimi łaskami. Najistotniejszym zaś owocem Mszy św. jést Komunia św. Dążyć więc należy do tego, by wierni nie zadowalniali się t. zw. komunią duchowną, lecz o ile możności na każdej Mszy św. przystępowali do Komunii św. sakramentalnej.

Otóż mamy pierwszy krok aktywnego udziału wiernych we Mszy św., który streścić można w dwóch zdaniach: 1. wierni ofiarują Jezusa i w Jezusie siebie samych, czego zewnętrznym wyrazem może byé datek ofiarny, oraz 2. wierni przyjmują komunię duchownă, a lepiej sakramentalną.

Te dwa postulaty stanowią podstawę, bez której nie może być mowy o jakimkolwiek racjonalnym aktywnym udziale wiernych we Mszy św.

II.

Pytamy dalej. czy możliwy jest jeszcze bardziej czynny udział wiernych we Mszy ŝw. Otóż poszczególne części Mszy św. domagają się swoistego udziału wiernych, podobnie jak poszczególne pokoje mieszkania o różnym przeznaczeniu domagają się od mieszkańców swoistego potraktowania ich.

Już sam podział Mszy św. na nabożeństwo słowa (od początku do Credo) i nabożeństwo czynu (od ofiarowania do końca) wskazuje, że w pierwszej części wierni nastawić się muszą na pewien 
rodzaj rozmowy między Bogiem a ludźmi, podczas gdy druga część nastawia na spełnienie jakiegoś czynu. Zgodne to jest ze słowami Jezusa: „Nie każdy, który mówi mi: Panie, Panie, wejdzie do Królestwa niebieskiego, lecz który czyni wolę Ojca mego".

Szczególowo zaś nabożeństwo słowa domaga się od wiernych najpierw, by szukali Boga na modlitwie (od początku aż do. kolekty), po tem by słuchali (Lekcja, Ewangelia, kazanie), a w końcu przyjąwszy nauki Boże wyznali swoją wiarę (Credo). Udział tedy wiernych w Przedmszy streszcza się w słowach: prosić — słuchać wyznać wiarę.

W drugiej zaś części, w nabożeństwie czynu, następuje najpierw na ofiarowanie czyn ludzki polegający na zaofiarowaniu chleba i wina wzgl. w zastępstwie tego na ofiarowaniu datku pieniężnego, potem w Kanonie czyn Boski, w której to części liturgia przydziela wiernym rolę tylko na początku w aklamacjach na prefację $i$ na końcu przez głośne Amen jako potwierdzenie dokonanej akeji ofiarnej a w ciągu Kanonu każe wiernym zachować święte milczenie, a w końcu w Komunii św. czyn bosko-ludzki, gdy wierni przystępują do uczty Pańskiej przygotowanej im przez Boga.

Streszczamy udział wiernych w nabożeństwie czynu znowu w trzech słowach: wejście w ofiarę na ofiarowanie - nabożne skupienie w Kanonie - uczestnictwo w uczcie ofiarnej.

\section{III.}

Msza św. składa się z szeregu ceremonii o swoistym zabarwienìu. Swoisty też musi być udział wiernych w tych poszczególnych cerèmoniach.

1. Liturgia przepisuje odpowiednią postawe zewnętrzna wiernych. Na ogół nasi wierni wstają na Ewangelię, klękają na podniesienie i Komunię, żegnają się tylko na Ewangelię. Jeśli na razie jeszcze urgować nie będziemy innej postawy i innych gestów, to przypilnować trzeba, by przynajmniej te, które lud zachowuje, spełnione były akuratnie, a więc by wierni liturgicznie wykonywali znak krzyża św., wielki i mały, by ich klękanie istotnie oznaczało akt uczczenia Boga, podobnie i bicie się w piersi. Można by tylko zażądać, by przy przyjściu kapłana do ołtarza i odejściu zajęli postawę stojącą, oraz zachęcić ich do częstego żegnania się razem 
z kapłanem np. na początku ministrantury, na końcu Gloria i Credo, na Benedictus.

Swoją postawą i swoimi znakami wierni zaświadezają, że śledzą akcję mszalną, że więc biorą w'niej aktywny udział.

2. W ciagu mszy spotykamy liczne wezwania kapłana, na które oczekuje od ludu odpowiedzi. Dotąd tylko ministrant, albo sam organista, albo chór poczuwali się do obowiązku zareagowania na zwroty kapłana skierowane wyraźnie do wszystkich. Pierwotne założenie tych wezwań oraz sama grzeczność nakłada na cały lud obowiązek dania kapłanowi odpowiedzi. Tego chyba szczegółowo udowodnić nie potrzeba. Te odpowiedzi mówione lub śpiewane przez lud walnie przyczyniają się do ożywienia nabożeństwa.

3. Rola wiernych uwydatnia się dalej w uczestnictwie w t. zw. śpiewach, których mamy dwa rodzaje. Pierwszy to śpiewy state: Kyrie, Gloria Credo, Sanctus wraz z Benedictus, Agnus Dei. To sa śpiewy par excellence ludowe. Bezwzględnie rależy do tego dążyć, by lud tutaj znowu doszedł do swego uprawnionego głosu.

Kapłan, wprowadzając śpiewy stałe w czyn, wyjaśni najpierw ludowi ich znaczenie i każe je wspólnie odmawiać najpierw po polsku w pełnym tekście mszalnym. Kyrie odmawiają wszyscy głośno na przemian z kapłanem. Gdy kapłan zapoczątkowuje Gloria czy Credo po łacinie, wszyscy głó́no recytuja po polsku. Sanctus i Benedictus odmawiają zaraz po prefacji. Agnus Dei wszyscy recytuja i biją się w piersi, podezas gdy kapłan odmawia swoje po cichu.

Jeśli te śpiewy mają byé przez lud śpiewane po polsku, to natrafimy na trudności wynikające z braku odpowiednich nut pod polski dosłowny tekst mszalny. Znam tylko jedną taką próbę Brunona Poznańczyka „Łatwa msza polska" w stylu gregoriańskim, gdzie Credo jest jednak apostolskie a nie mszalne. Próba moim zdaniem udatna, naśladowania godna. Tutaj należałoby zachęcić muzyków do ułożenia co najmniej z pięć melodii z polskim tekstem mszalnym, może z uwzględnieniem kolorytu poszczególnych okresów roku kościelnego (na czas gwiazdkowy, wielkanocny, Zielonych Swiątek, Święta Matki. Boskiej i na czas ogólny). Jak na razie trzeba będzie się zadowolić parafrazą śpiewów stałych, jaką znajdziemy w rozmaitych $t$. zw. mszach polskich.

Dążyć naleźy ostatecznie do tego, by lud te śpiewy stałe kiedyś wvkonać umiał no łacinie w melodii gregoriańskiei. Należy wv- 
Zostając jeszcze przy temacie śpiewów stałych, należy za wszelką cenę unikać innych przygodnych pieśni. Ojciec św. Pius XII wyraźnie powiada, by „lud śpiewał pieśni dostosowane do różnych części Mszy św." (str. 69). Inaczej bowiem mogą wyniknąć takie anomalia, że np. kapłan intonuje Gloria, czyli pragnie, by w tej chwili lud razem z nim oddał chwałę Bogu, a tymezasem lud śpiewa Serdeczna Matko, albo gdy na Credo, gdzie ma nastąpić publiczne wyznanie wiary, wszyscy śpiewają Kiedy ranne. Świadomy i aktywny wierny będzie się dzisiaj gorszył takimi sprzecznościami.

Jeśli chór śpiewa, niech $\mathbf{i}$ on dostosuje się do liturgii mszalnej.

4. Trudniej przedstawia się sprawa ze Śpiewami zmiennymi, w których i lud może brać udział. Do nich zaliczamy: Introit, Graduał i Alleluja, czasami Traktus i Sekwencja, Offertorium i Communio.

Introit odgrywa $w$ dramacie mszalnym rolę prawdziwej uwertury. Ten śpiew wykonywano, gdy celebrans z asystą zbliżał się do ołtarza, odmawiając po drodze ministranturę. Dziś kapłan przy oltarzu po prostu dogania Introit, a stało się to tak od chwili, gdy zaczęto odprawiać msze ciche. Dziś w okresie ożywienia liturgicznego, Introit powinien stać się napowrót prawdziwym śpiewem otwierającym nabożeństwo. Lud powinien go śpiewać, podczas gdy kapłan wychodzi z zakrystii i longinqua via kroczy w towarzystwie licznych ministrantów ku ołtarzowi.

Graduał chce być oddźwiękiem co dopiero wysłuchanej Lekcji, a wiersz Alleluja przeddźwiękiem mającej nastąpić Ewangelii. I Traktus odpowiednio śpiewany, a również rozszerzone Alleluja w ezasie wielkanocnym, oraz niekiedy sekwencja przyczyniają się do nadania żywości akcji liturgicznej.

Offertorium, śpiewane kiedyśs podczas procesji wiernych z darami ofiarnymi, miało pogłębić ducha ofiarnego wiernych.

Communio jest śpiewem podczas rozdzielania Komunii św., dziś kapłan również dogania go po cichu już po komunii wiernych. Krótki ten wiersz komunijny sprawia, że widzimy Pana Jezusa wstępującego do serca za każdym razem w innym naświetleniu.

Jeśli idzie o udział wiernych w śpiewach zmiennych, trudność polega na tym, że nie wszyscy posiadają mszaliki, a jeśli mają, to nierówne teksty. Temu zaradzić można w różny sposób: 
a) Lektor mający mszalik czyta je głośno tak podezas mszy cichej jak i przez lud śpiewanej. Ładniej wypadnie to, gdy kilku lektorów podzieli się w odczytaniu poszczególnych wierszy, odpowiednio do łacińskiego wykonania (o czym osobno).

b) Podezas mszy śpiewanej, może chór zaopatrzony w równe mszaliki, a przynajmniej w równe teksty, odśpiewać je recitando z podzieleniem się na preceptora, półchór i cały chór. Psalm Introitu można by zaśpiewać na jakąś melodię psalmu, a lud na tę samą melodię zaśpiewał by Chwała Ojcu.

c) Gdy chór śpiewa po łacinie, nigdy nie powinien opuszczać śpiewów zmiennych, co niestety u nas bardzo często się zdarza. Niechby zaś zaśpiewał chociaż recitando.

d) Namiastką właściwych śpiewów zmiennych z tekstem mszalnym moga byé pewnego rodzaju parafrazy, jakie znajdziemy w polskich mszach, np. na Introit, Gradual itd.

e) W najgorszym wypadku można je zastąpić polskimi pieśniami okolicznościowymi lub okresowymi, np. na Gwiazdkę kolędami, gdyż śpiewy zmienne mają za zadanie podtrzymać nastrój danego dnia czy okresu.

Uwa gi: Mówiąc łącznie o śpiewach stałych i zmiennych, nasze msze polskie n. p. "Nieogarniony", czy ,Przed Twoim troneni" mniej więcej odpowiadają wymaganiom liturgicznym pod tym względem. W prawdzie nie oddają nastroju danego czasu, lecz przynajmniej ilustrują akcję, jaka w tej chwili odbywa się przy ołtarzu.

Lepiej to zrobił ks. Stanisław Poczta, gdy w swoim „Mszaliku obrazkowym" bardziej jeszcze uwzględnił nastroje okresowe. Ma więc msze adwentową, przy czym uwzględnia jeszcze np. na Introit pierwsza, drugą, trzecia i czwartą niedzielę adwentu, - potem dwie msze Gwiazdkowe, - mszę wielkopostną, - wielkanocną, potem msze na cztery niedziele miesiąca, — każda inna, — na święta Pana Jezusa i święta Matki Boskiej, mszę żałobną, — razem 12 mszy bardzo zbliżonych w tekstach do Liturgii roku kościelnego. Teksty dorobił do melodii znanych.

5. Przechodzimy teraz do omówienia udziału wiernych w modlitwach mszalnych, do których należą: kolekta, sekreta i postcommunio. Są to modlitwy zmienne. Kolekta stanowi modlitwę wspólną na początku nabożeństwa, streszcza ona we formie prośby myśl danej uroczystości, postcommunio zaś na końcu na- 
bożeństwa błaga o dobre wykorzystanie owoców Mszy św. Te dwie modlitwy, jako że są głośno odmawiane przez kapłana wzgl. śpiewane, bez wątpienia przeznaczone są dla ludu, tym bardziej, że kapłan słowami "Oremus", zaprasza wiernych do wspólnej modlitwy. Inaczej jest ze sekretą, która jest istotnie cichą modlitwą samego kapłana na zakończenie ofiarowania.

O treści tych modlitw wierni w jakiś sposób powinni się dowiedzieć. Gdy mają mszaliki, kwestia łatwo rozwiązana, lecz gorzej, gdy ich nie posiadają. Na cichej mszy lektor, mający mszał polski, może je głośno czytać, jednak tak, by kapłan na początku głośno mówił „Oremus", a na końcu znowu głośno ,Per omnia saecula saeculorum", aby w ten sposób wierni odpowiadali ,amen" kapłanowi, a nie lektorowi.

Trudna sprawa, gdy Msza św. jest śpiewana. Tutaj już trzeba zadowolić się tym, że wierni nie mający mszału. choć w intencji łączą się z kapłanem, a w końcu głośno odpowiadaja „amen“.

Sądzę, że niewłaściwym byłby sposób, który tė̇ widziałem, by po odśpiewaniu modlitwy przez kapłana po łacinie lektor jeszeze potem prędko przeczytał ją po polsku, - albo by kapłan zaśpiewał "Oremus", dalszy ciąg po cichu odmawiał, a w międzyczasie lektor po polsku czytał i znowu kapłan na końcu zaśpiewał „Per omnia s. s."

Co do Sekrety nie ma trudności, bo kapłan zawsze mówi ją po cichu. Lektor więc mógłby ją spokojnie czytać, nawet gdy msza jest śpiewana.

6. Trzy są nauki przeznaczone dla ludzi: Lekcja, Ewangelia i kazanie. Ze swoimi naukani występują w Lekcji prorok albo apostoł, w Ewangelii Pan Jezus, w kazaniu Kościół św.

O kazaniu wygłoszonym w języku zrozumiałym przez lud nie ma wiele co mówić, chyba to, by istotnie ono znalazło swoje miejsce po Ewangelii a przed Credo, kazanie bowiem należy według starego zwyczaju do liturgii i dlatego też w każdym kazaniu powinno się w jakiś sposób nawiązać do Mszy św., jako że w ofierze eucharystycznej słowa stają się ciałem.

Co zrobić z Ewangelią, a zwłaszcza z Lekcja, by lud miał korzyści z nauk, jakie liturgia przeznacza dla niego?

I znowu łatwe rozstrzygnięcie, gdy idzie o mszę czytaną. Wtedy bowiem lektor może je głośno czytać w czasie, kiedy kapłan czyta 
po łacinie; kapłan musi to czynić nieco wolniej. Bardziej odpowiednio byłoby, gdyby kapłan sam czytał ewangelię po swojej ewangelii, a stanem idealnym byłoby już to, gdyby na każdej mszy nawet w dzień powszedni czytał po polsku perykopy dnia (a nawet krótko je objaśnił wzgl. przede Mszą św.).

Większą trudność nastręcza msza śpiewana. Rozwiązanie znalazło by się w tym wypadku, gdyby kapłan zechciał po swojej ewangelii przeczytać po polsku i Lekcję i Ewangelię. Innej rady nie ma, gdy wierni nie posiadaja polskiego mszalika.

Oto wielkie pole dla wiernych, by zaznaczyli swój aktywny udział w liturgii mszalnej: postawa zewnętrzna, odpowiedzi, śpiewy stałe, śpiewy zmienne, modlitwy, nauki.

IV.

I pytamy dalej, czy zachodzi jeszcze gdzie we Mszy świętej możliwôść uaktywnienia wiernych.

1. Co sądzić o ministraniurze? Z ks. Piusem Parschem jestem zdania, że ona nie należy zasadniczo do ludu. Nigdy jej celebrans nie odmawiał $\mathrm{z}$ ludem, lecz tylko $\mathrm{z}$ asystującym mu klerem $\mathrm{i}$ to podczas pochodu do ołtarza, gdy wierni śpiewali Introit. Dziś ministrant $u$ stopni ołtarza nie zastępuje ludu, lecz dawniejsze duchowieństwo.

Niema jednak przeszkody, by lud niejako prywatnie zmówil ją naprzemian z lektorem, albo na początku Mszy św. podezas ministrantury kapłana, albo we wypadku śpiewania introitu zaraz przy wyjściu kapłana z zakrystii, nawet przede Mszą św. (o Mszy dialogowanej, w której wierni po łacinie odmawiają ministranturę z kapłanem, będzie jeszcze osobno mowa).

2. Uaktywnienie ofiarowania. Dawniej lud brał bardzo czynny udział w ofiarowaniu, raz że w procesji podchodził do ołtarza ze swoimi darami chleba i wina oraz innymi na utrzymanie kościoła, biednych i duchowieństwa, a po wtóre, że podczas procesji śpiewał Offertorium. Rola zaś kapłana polegała na tym, że odbierał dary, po czym wezwawszy słowami ,Orate fratres ${ }^{66}$ swych współkapłanów do modlitwy, odmawiał sekretę, cichą modlitwę nad złożonymi darami. 
Później po ustaniu procesji ofiarnej pouzupełniano uszczuploną liturgię dodatkowymi modlitwami kapłana, które nazywamy „małym kanonem“6.

Powstaje kwestia, czy i jakby można dzisiaj przeprowadzić jakieś uaktywnienie wiernych na ofiarowanie.

a) już podkreśliliśmy znaczenie datku pieniężnego jako namiastki dawniejszej procesji ofiarnej. Dawniej wierni zbliżali się do ołtarza, dziś niejako ołtarz zbliża się do wiernych we form'e zbierającego ofiarę. Zhbieranie składki powinno zasadniczo rozpocząć się na ofiarowanie. Można by też zastanowić się nad tym czy nie dało by się tego zbierania przeprowadzić w jakiejś formie bardziej uroczystej, n. p. z świecą.

b) jeśli gdzie istniał albo jeszcze dziś istnieje zwyczaj, że wierni na ofiarowanie obchodzą ołtarz, należy go pielęgnować i pogłębić wzgl. na nowo wskrzesić.

c) Czy można by wskrzesić zwyczaj zanoszenia przez wiernych chleba i wina do ołtarza? Papież Pius XII w swej encyklice o liturgii przy udowadnianiu, że i lud bierze udział we Mszy św. przytacza między innymi i ten dowód, że, lud nieraz przynosi kapłanowi, co dawniej częściej się zdarzało, chleb i wino" (str. 64). Z tych słów wynika, że zasadniczo takiemu obrzędowi nic nie stało by na przeszkodzie, tym bardziej, że był to powszechny zwyczaj w starym kościele. Można by mieć zastrzeżenia tylko co do sposobu przeprowadzenia takiej akcji, np. we wielkiej parafii.

W Tyńcu praktykuje się w ten sposób, że na Mszę św. o mniejszej frekwencji na ofiarowanie każdy z pragnących przystąpić do Komunii św. bierze komunikant z koszyczka ustawionego przy balaskach i wkłada go do puszki, którą kapłan potem odbiera i ofiaruje przy ołtarzu. Na wypadek wielkiej frekwencji np. przy Komunii św. dzieci, wybiera się kilku przedstawicieli, którzy czynią to za innych. Przekładanie komunikantów uskutecznia się palcami lub pincetą.

Natomiast można by z racji większych świąt (nie w każdą niedzielę) zorganizować zbiórkę darów w naturaliach, t. zw. dary ołtarza. Powiedzmy, że na Gwiazdkę albo na Wielkanoc wierni przynoszą jakieś paczki dla biednych, które składają przy wejściu do kościoła w przygotowany kosz, a na ofiarowa- 
nie wydelegowani spośród wiernych zanoszą go do ołtarza. W ten sposób zaznacza się ścisły związek miłosierdzia chrześcijańskiego z ołtarzem.

d) Czy wienni moga po polsku recytować w czasie ofiarowania wszystkie modlitwy, które kapłan po cichu odmawia, t. zw. mały kanon? Zasadniczo są to modlitwy ściśle kapłańskie, a więc nie domagają się udziału wiernych. Tychże rolą jest w czasie ofiarowania śpiewać offertorium, dawniej z psalmem. Jednakże dla zapoznania wiernych z treścią małego kanonu i pogłębienia ich ducha ofiarnego można je wspólnie recytować, nie koniecznie zawsze wszystkie, możnaby ograniczyć się np. do jednej z trzech modlitw of iarnych i ,Lavabo“".

Zaznaczyć trzeba, że słowa „Orate fratres" skierowane były dawniej przez celebransa do współcelebrującego kleru, odpowiedź tedy należy nie tyle do ludu, lecz do ministranta, w tym wypadku zastępującego kler. Nie było by jednak nic zdrożnego gdyby w czasie, gdy ministrant odmawia „Suscipiat ${ }^{6,}$, lud odmawiał tę odpowiedź po polsku. Na końcu niech kapłan powie dość głośno „Amen“.

3. Udział wiernych w Kanonie, jak już mówiliśmy, ogranicza się tylko do aklamacji w prefacji oraz do potwierdzającego ,amen ${ }^{66}$ na końcu przy małym podniesieniu. Według zwyczaju rzymskiego ma w czasie kanonu panować święte milezenie chyba, że lud śpiewa „sanctus“" przed i ,benedictus“ po podniesieniu.

Przy wspólnej recytacji po polsku może lud odmówić przyciszonym głosem modlitwę ,Ciebie więc“ zaraz po ,,sanctus", oraz „Przeto Panie“ zaraz po podniesieniu. W tych bowiem modlitwach przebija się myśl o współudziale ludu w ofierze. Poza tym może lektor krótkimi uwagami zaznaczyć mementa w Kanonie. Dawniej diakon również odezytywał dyptychy.

Na ogół cisza w kanonie robi głębokie wrażenie na wiernych, spotęgowane tym, że nagle odezwie się dzwonek na podniesienie. Znak dzwonkiem powinien nastąpić w porę, aby wierni mieli czas uklęknąć i mogli spokojnie śledzić ruchy kapłana naśladującego tutaj Jezusa już od pierwszej czynności konsekracyjnej, tj. gdy kapłan bierze chleb do ręki.

Do ożywienia udziału wiernych w kanonie przyczynić się moga również przyniesienie zapalonych świec na ,sanctus", a także pod- 
trzymanie ornatu celebransa przez ministrantów w czasie podniesienia, oraz dzwonienie $w$ dzwon na podniesienie.

4. Udział wiernych w trzeciej głównej części Mszy św., nazwanej Komunią, znowu się ożywia. Moga odmówić wspólnie „Ojcze nasz ${ }^{46}$ jako pacierz przed ucztą, modlitwę „Libera“, a następnie po „Pax Domini“ również modlitwę o pokój oraz dwie modlitwy przygotowaweze do Komunii św. Wierni powinni zawsze mieć okazję do przystąpienia do stołu Pańskiego w czasie Mszy zaraz po komunii kapłana, a nawet mogą wyrazić swoje życzenie, .,aby hostie przez nich spożywane, były zakonsekrowane na tej samej mszy " (str. 73). To już mówiliśmy, by wierni o ile możności przystępowali na każdej mszy św. do komunii sakramentalnej.

Przed komunią wiernych sami ministranci odmawiają „Confiteor" po kacinie, natomiast lud może trzy razy odmówić „Panie nie jestem godzien " (kapłan mówi po łacinie). Na wypadek dłuższego rozdzielania Komunii św. można zaśpiewać pieśni eucharystyczne, albo nawet wiersz komunijny ,Communio“".

Mówiąc o Komunii św. wiernych, warto zastanowić się, czy nie dałoby się w sposób godny a zarazem łatwy zorganizować samo zbliżanie się wiernych do balasek oraz ich odejście od nich, zwłaszcza gdy frekwencja jest wielka. Mam wrażenie, że ścisk (tak ulubiony przez polski lud) i nieład, jaki niejednokrotnie tu panuje. bynajmniej nie licuja z powaga danej chwili i wcale nie zachęcaja do częstszego komunikowania. Tej kwestii należy stanowczo poświęcić więcej uwagi, oczywiście każdy duszpasterz indywidualnie musi rozejrzeć się w możliwościach i środkach zaradzenia temu złu. Już wielce pożyteczną rzeczą będzie zarządzić, by wierni zbliżali się do kratek stojąco a nie klęcząco, by zostawili pewien odstęp między klęczącymi przy halaskach a pierwszym szeregiem zbliżających się, i by zawsze pierwszeństwo mieli ci, którzy z Jezusem w sercu wrarają do swoich miejsc. Można by też starszych ministrantów albo t. zw. marszałków postawić dla utrzymania porządku.

6. Udział wiernych w zukończeniu Mszy św. Wszyscy wierni klękaja na błogosławieństwo kapłańskie i pięknie by brzmiało, gdyby wszyscy po polsku wtedy mówili: „Niech nas błogosławi wszechmogący Bóg, Ojciec i Syn i Duch święty. Amen".

Zaznaczyć trzeba, że Ostatnia Ewangelia, tj. prolog św. Jana zasadniczo nie jest przeznaczona dla ludı. Dzieje Mszy św.. uczą 
nas, że był to rodzaj modlitwy dziękczynnej kapłana, czy nawet błogosławieństwa. Nie stoi jednak nic na przeszkodzie, by i lud raz po raz recytował ją dla zapoznania się z jej treścią.

Jeśli idzie o modlitwy po cichej Mszy św. proponuję, by antyfonę „Witaj Królowo" odmawiał cały Iud.

Gdy kapłan odchodzi od ołtarza, a może nawet już podezas Ostatniej Ewangelii, lud może śpiewać jakąś pieśń okresową albo psalmy dziękczynne. W ogóle warto pomyśleć i o tym, aby lud wspólnie odprawiał dziękczynienie po Mszy św.

Oto możliwości racjonalnego uaktywnienia udziału wiernych w Najśw. Ofierze. Lud byłby stale zajęty, a cała Msza św. zyskała by na dramatyczności i urozmaiceniu.

\section{B. REALIZACJA}

Od możliwości daleka jeszcze droga do realizacji. Sama liturgia podsuwa powyższe możliwości, lecz dzisiejsze okoliczności oraz nasze warunki w porównaniu do idealnych czasów starochrześcijańskich każą duszpasterzowi roztropnie spośród nich wybrać te, które okażą się w jego środowisku możliwe do zrealizowania.

Prócz zapału potrzebna tu koniecznie wielka roztropność, by czasami nie wpaść w przesadę albo też i manię niegodnego próbowania w kościele, przed czym ostrzega Ojciec św. Pius XII pisząc: „Niech wszystko odbywa się w należytym porządku i z godnością i niechaj nie będzie wolno nikomu, nawet kapłanowi, dowolnie używać kościoła do jakichś eksperymentów" (str. 70).

\section{Idealy tacińskie}

1. Ideałem Mszy św. jest Msza uroczysta z asystą, podczas której chór śpiewa wielogłosowo albo po gregoriańsku, wszystko po łacinie. Lud śledzi wtedy Mszę z mszalików, mały tedy bierze czynny udział. Nie mniej jednak i takie msze mają się odprawiać i to z tej racji, że — jak pisze Ojciec święty — „ta bowiem, chociaż odprawiana tylko przy udziale asysty, posiada jednak szczególną godność z powodu okazałości i świetności obrzędów i ceremonii. Ta świetność jeszcze bardziej się wzmaga, jeśli lud pobożny gro-

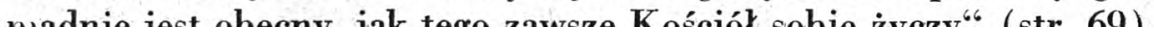


2. Drugi ideał łaciński z większym udziałem wiernych. Missa cantata. Wszyscy używają mszalika. Chór wykonuje części zmienne po łacinie, wierni śpiewają śpiewy stałe po gregoriańsku oraz wszystkie odpowiedzi. To ideał, do którego w naszych warunkach można i powinno się dążyć.

3. Trzeci ideał łaciński to tzw. msza dialogowana. Jest to missa lecta. Poza odpowiedziami łacińskimi wierni odmawiają wspólnie z celebransem po łacinie: ministranture, Kyrie, Gloria, Credo, Suscipiat, Sanctus i Benedictus (nie Pater Noster) i Agnus Dei oraz przy Komunii św. Domine, Non sum dignus. Moga też wybrani lektorzy głośno z celebransem recytować po łacinie śpiewy zmienne: Introit, Graduał. Alleluja, Offertorium, Communio. Ten sposób nadaje się dla grona znających język łaciński, gdzieś po kaplicach. Zasadniczo nie powinien lektor czytać części zmiennych po polsku, gdyż kapłan wszystkie części przeznaczone dla ludu mówi tak głośno, że wierni je dobrze słyszą, a jako znający język łaciński, równiez rozumieją. Dopuszczalne wprawdzie i tu są wyjątki. Na Mszę dialogowaną wystarcza cicha zgoda ordynariusza, który musi mieć pewność, że wszyscy prawidłowo wymawiają teksty łacińskie.

\section{Ideaty polskie.}

Wobec niemożliwości wzgl. trudności przeprowadzania w naszych warunkach powyższych ideałów łacińskich, trzeba szukać jakiegoś ideału polskiego. Wystąpi on w trojakiej formie:

1. Missa cantata. Wierni mają mszaliki. Cały lud śpiewa odpowiedzi. Chór śpiewa sam po polsku polifoniczne śpiewy stałe i ewent. jakieś motety np. na ofiarowanie. Chór jednak zawsze dodaje teź śpiewy zmienne po polsku. Udział ludu mały, tyle że śpiewa odpowiedzi.

2. Jak poprzednio z tạ tylko różnicą, że lud śpiewa stałe jednogłosowe części po polsku (nuty Brunona Poznańczyka), w stylu gregoriańskim.

3. Jak poprzednio, tylko że lud śpiewa tzw. polskie msze wzgl. pieśni ułożone przez ks. Stanisława Pocztę.

Mam wrażenie, że ten trzeci sposób polskiego ideału powinien jako najłatwiejszy przyjąć się u nas, chociażby tylko w pewne niedziele i święta. Idealny byłby też to sposób na odpustach. 


\section{Stopnie przygotowawcze $i$ przejściowe}

Aby lud doszedł do powyższego ideału i rzeczywiście ze zrozumieniem brał udział $w$ takiej wzorowej mszy, należy go do tego doprowadzić po pewnych stopniach przygotowawezych.

1. Powoli wprowadzić mszę recytowaną po polsku. Jest to missa lecta, podezas której wierni odmawiają po polsku wspólnie modlitwy mszalne. Użytecznym tu okaże się podręcznik ks. Śpikowskiego „Liturgiczna msza wiernych“, który albo wierni nabędą sobie na własność, albo parafia im wypożyczy. Poszczególne stopnie musi kapłan najpierw ludowi wyjaśnić i z nim przeéwiczyć.

a) lud wykazuje swoją aktywność najpierw jedynie w odpowiedziach łacińskich na wezwanie kapłana.

b) Lektor mający mszał odczytuje wszystkie części zmienne.

c) Lud recytuje śpiewy stałe.

d) Powoli wprowadza się recytację innych części Mszy św. np. ministranturę, dalej ofiarowanie, potem Kanon itd. W praktyce okazało się, że wierni wolą odrazu odmawiać całość.

W ten sposób lud recytuje wszystko od początku do końca. Kapłan w tym wypadku musi zwolnić tempo odprawiania Mszy św. Dobrze, by wtedy swoje modlitwy i gesty dostosował do tempa recytacji polskiej, a więc tak, by np. kapłan i wierni równocześnie żegnali się.

Przećwiczenie takiej mszy recytowanej przez pewien dłuższy okres jest konieczne, by wierni dokładnie rozpoznawali poszczególne części Mszy św., do czego zresztą kapłan musi im dopomóc przez małe wyjaśnienia przed każdą Mszą św.

Przy wspólnej recytacji okazał się tonus rectus jako zbyt trudny i uciążliwy. Dobre również wyniki osiągnięto, gdy każdy mówił w swojej własnej tonacji — wyjdzie wtedy taki ogólny ton, jakby przy różańcu. Wprawdzie ładniej brzmi tonus rectus, lecz ten nadaje się tylko w pewnych małych zgromadzeniach dla ludzi o dobrym słuchu, by uniknacé detonowania.

Msza recytowana może się z czasem sprzykrzyć, toteż nigdy nie wolno przedstawiać jej jako cel, lecz tylko jako środek do wyższego ceiu tj. jako środek do głębszego zrozumienia Mszy św. i jako przygotowanie do innych jeszcze sposobów czynnego uczestniczenia we Mszy św. Trzeba jednak na końcu zaznaczyć, że bardzo lubianym sposobem uczestniczenia w cichej Mszy okazał się sposób pod nr 
a, b, c, łącznie praktykowany, tzn. lektor czyta wszystkie części zmienne wraz z Prefacją, a lud recytuje ezęści stałe po polsku oraz daje odpowiedzi łacińskie. W odpowiednich pauzach lud woli sam modlić się po cichu. Ten sposób nadaje się bardzo na Mszach cichych dla grona, które już zna wszystkie części Mszy św.

2. Missa lecta, lecz ze śpiewami polskimi.

a) Wszystko jak poprzednio z tym tylko, że lud śpiewa śpiewy stałe.

b) Lud dodaje śpiewy zmienne. Gdzieby między śpiewami miały zostać pauzy, tam lektor, wzgl. wszyscy wierni recytują.

Taka Msza wyglądałaby w ten sposób: Lud odmawia ministranturę przed Mszą św. Gdy kapłan wychodzi z zakrystii, lektor czyta „Introit", i zaraz potem lud śpiewa coś na Introit. Kyrie wierni odmawiają wspólnie z kapłanem. Na Gloria śpiew (kapłan czeka końca śpiewu). K̇olektę aż do Ewangelii włącznie lektor czyta z mszału. Credo śpiewane (kapłan odmawiający po cichu, czeka końca śpiewu). Na ofiarowanie lektor czyta Offertorium i Sekretę, a w pośrodku lud śpiewa. Po prefacji czytanej przez lektora śpiew Sanctus przed podniesieniem. Po podniesieniu śpiew Benedictus. Po Pater Noster wszyscy recytują Libera, na Agnus Dei lud śpiewa i jeśli zostanie trochę czasu przed komunią wiernych, wszyscy recytują jẹdną lub drugą modlitwę przed komunią św. W czasie rozdawania Komunii św. Communio i Postcommunio lektor czyta. Na błogosławieństwo kapłana wszyscy głośno mówią. Przy odejściu kapłana od ołtarza jakiś śpiew.

3. Missa cantata, tj. śpiewana przez kapłana. Zasadniczo podczas missa cantata nie wolno śpiewać po polsku, lecz gdzieby taki istniał długoletni zwyczaj przy cichej aprobacji ordynariusza, co właśnie ma miejsce $u$ nas $w$ Polsce, to tam tego zwyczaju bez wiedzy biskupa nawet zmieniać nie wolno.

Różnymi sposobami można ożywić udział wiernych w mszy śpiewanej.

a) Kapłan śpiewa co do niego należy. Lud odpowiada po Kacinie a w odpowiednich przerwach recytuje módlitwy po polsku.

b) Lud śpiewa pieśni stałe, a gdzie można, recytuje.

c) Jak poprzednio, lecz tu chór śpiewa po polsku śpiewy zmienne recitando.

I w ten sposób dochodzimy do polskiego ideału wyżej wymienionego. 
Zaznaczamy jeszcze raz, że wszystkie przejściowe stopnie są tylko przejściowymi, lecz koniecznymi, by lud mógł z pełnym zrozumieniem dojść do możliwie najidealniejszego w polskich warunkach uezestniczenia 'we Mszy św.

Po przyjrzeniu się nam wszelkim możliwościom, okazuje się, że u nas mogłyby się ustalić następujące typy mszy:

1. Missa cantata z tacińskim śpiewem chóru. Lud śpiewa tylko łacińskie odpowiedzi. Chór śpiewa także śpiewy zmienne po łacinie.

2. Missa cantata z polskim śpiewem chóru. Chór śpiewa śpiewy zmienne po polsku recitando, i śpiewy stałe wielogłosowe. Lud śpiewa tylko odpowiedzi łacińskie.

Te dwa typy dają chórowi szerokie pole do popisu.

3. Missa cantata z polskim śpiewem ludu. Chór śpiewa śpiewy zmienne po polsku recitando, a lud resztę jednogłosowo, wzgl. lud śpiewa wszystkie śpiewy po polsku.

4. Missa lecta z recytacja ludu bez śpiewu. Lektor czyta częŝci zmienne, lud recytuje albo wszystko, albo częściowo.

5. Missa lecta $z$ recytacją ludu $i z$ polskim śpiewem. Lektor czyta części zmienne. Lud śpiewa śpiewy stałe, a w pauzach recytuje.

\section{PLAN PRACY LITURGICZNEJ}

Z a n im powiemy o planie pracy liturgicznej, nie można na tym miejscu nie wspomnieć najpierw o pewnych ważnych wskazówkach Ojca św. Piusa XII (str. 69-70). Z jednej strony papiė pochwala tych, „którzy pragna ułatwić udział ludu wiernego we mszy i zapewnić mu zbawienniejsze skutki, dają mu do rąk ,mszał rzymski", a także tych, „którzy się starają aby liturgia i na zewnątrz stała się czynnością świętą, w której wszyscy obecni uczestniczą". Sądzę, że powyższe nasze wysiłki należą właśnie do tych pochwały godnych. Z drúgiej jednak strony papież ostrzega przed dwiema przesadami: raz przed mniemaniem, ,jakoby ofiara bez tych zewnętrznych oznak ludu nie nosiła charakteru publicznego i wspólnego", a po wtóre, by „taką przywiązywać wagę do tych okoliczności dodatkowych, iż nie wahamy się twierdzić, że bez nich Msza św. nie może osiągnąć naznaczonego jej celu".

I tu warto dosłownie przytoczyć pewne zastrzeżenia, które ma papież pod tym względem. 
1. "Wielu wiernych nie potrafi używać Mszału Rzymskiego, choćby wydanego w języku potocznym".

2. Nie wszyscy są zdolni zrozumieć właściwie i jak należy obrzędy i formuły liturgiczne".

3. ,Umysly, charaktery i temperamenty ludzi są tak rozmaite i między sobą nie podobne, że modlitwy, śpiewy i obrzędy, wspólnie odprawiane, nie mogą ich w ten sam sposób wzruszyé i nimi kierowaéc.

4. .Ponadto potrzeby i skłonności nie są u wszystkich jednakowe, a i u każdego nie trwają bez zmian".

W konkluzji powiada papież: ,Któż by więc śmiał powiedzieć, trzymając się wspomnianych uprzedzeń, że tylu chrześcijan nie może brać udziału w Ofierze Eucharystycznej i korzystać z jej dobrodziejstw. I oni również mogą korzystać z owoców mszy, choć w inny sposób, dla niektórych łatwiejszy, jak np. rozważając tajemnicę Jezusa Chrystusa, lub tė̇ spełniając inne ćwiczenia pobożne i inne odmawiając modlitwy, które istotą swoją odpowiadają świętym obrzędom, chociaż formą się od nich różnią“"

Ze słów papieża wynika dla nas praktyczny wniosek, by wiernym dać pewną swobodę i nie zamęczać ich ciągłym wspólnym recytowaniem i wspólnym śpiewem. W powyższych typach uwzględniono ten postulat o tyle, że dwa zarezerwowane są prawie wyłącznie dla chóru, a lud tylko tyle uczestniczy czynnie, że odśpiewuje odpowiedzi łacińskie.

To jednak nie ma znaczyć, by w ogóle wszystkiego zaniechać. Wierni muszą przejść pewne przeszkolenie, co może trwać pewien dłuższy okres czasu. Głównie idzie tu o recytację. Już wspomnieliśmy, że może na dalszy dystans ludziom się sprzykrzyć. Jednakże cel został $w$ ten sposób osiągnięty, gdyż w skutku musi nastąpić lepsze zrozumienie Mszy św. w całości oraz w poszczególnych jej częściach. Gdy lud po prostu nauczy się na pamięć wszystkich modlitw mszalnych, wtedy można jeśli nie całkiem zaprzestać z recytacją, to przynajmniej ograniczyć ją dla odświeżenia pamięci wiernych do jednego czy drugiego razu na miesiąc.

Uważam za wskazane, by każdy proboszcz indywidualnie ułożył sgbie plan pracy liturgicznej odpowiednio do możliwości w swojej parafii. Taki plan obejmował by na sam przód niedziele miesiąca i to jeszcze z uwzględnieniem poszczególnych mszy, jakie się odpra- 
wiają. Gdzie możliwe, tam i na dnie tygodnia trzeba by ułożyé odpowiedni plan. Varietas delectat. Takiego planu nie można z góry każdenu narzucić, lecz każdy powinien istotnie sam go opracować.

W zakres planu wejść musi też praca nad uświadomieniem liturgicznym parafian, wyszukanie i wyszkolenie lektora wzgl. lektorów, éwiczenie odpowiedzi łacińskich, recytacje i śpiewy, sposoby przeprowadzenia tych i innych jeszeze wyżej wymienionych możliwości ożywienia wiernych na Mszy św. Będzie to po prostu plan pracy liturgicznej na dłuższy okres czasu.

Tutaj diecezjalne Rady Liturgiczne mają okazję służenia pomoca w układaniu planu oraz w przeprowadzeniu go w czyn. Musza też one wydać ogólne wskazówki dla wszystkich duszpasterzy.

Poznań

Ks. Dr WŁADYSŁAW ŚPIKOWSKI

\section{HISTORYCZNA TRADYCJA IZRAELSKA}

Jest rzeczą stwierdzoną, że jednym z głównych źródeł, na podstawie których zostały zredagowane znane nam dzisiaj księgi historyczne Starego Testamentu, była tradycja, czyli ustne przede wszystkim przekazywanie relacji o faktach historycznych. Zagadnienie wartości historycznej tej tradycji jako źródła stanowi jedno z naczelnych zagadnień historiografii izraelskiej ${ }^{1}$ ), zwłaszcza jeśli chodzi o okres najwcześniejszy dziejów Izraela, a mianowicie o początki tego narodu. Tradycja ta, stanowiąca treść dṛugiej części księgi Rodzaju (rozdziały 12-50) przede wszystkim, a następnie i pozostałych ksiąg Pięcioksięgu Mojżesza, przedstawia dzieje patriarchów protoplastów narodu izraelskiego, pobyt szczepów izraelskich w Egipcie, wreszcie epokę Mojżesza (wyjście z Egiptu i wędrówka Izraelitów po pólwyspie Synajskim).

Już od dawna wielu uczonych, jak J. Wellhausen, H. Gunkel, A. Lods, by wspomnieć wybitniejszych tylko, uważało biblijną relację o patriarchach izraelskich za twór wyobraźni ludu, za zbiór opowieści gminnych, pozbawionych wartości historycznej. W podobny sposób H. Gressman zakwalifikował i opisaną w Pięcioksięgu epokę Mojżesza ${ }^{2}$ ). Skutkiem tego negatywnego stanowiska

) Por. J. Jelito: $O$ historiografii biblijnej i starowschodniej, art. w "Ruchu Biblijnym i Liturgicznym" 2 (1949) $9-18$.

2) Por hose und seine Zeit, Göttingen 1913. 